\title{
The mRNA Expression of Serotonin 2C Subtype Receptors Uncoupled With Inositol Hydrolysis in NG108-15 Cells
}

\author{
Michihisa Tohda ${ }^{1}$, Monrudee Sukma $^{1}$, Yasuyuki Nomura ${ }^{2}$ and Hiroshi Watanabe ${ }^{1, *}$ \\ ${ }^{1}$ Department of Pharmacology, Institute of Natural Medicine, Toyama Medical and Pharmaceutical University, \\ Toyama 930-0194, Japan \\ ${ }^{2}$ Department of Pharmacology, Graduate School of Pharmaceutical Sciences, Hokkaido University, \\ Sapporo 060-0812, Japan
}

Received May 9, 2002 Accepted July 19, 2002

\begin{abstract}
Cell culture systems seem to be useful for clarifying the cellular physiological mechanisms of serotonin $2 \mathrm{C}$ subtype receptors $(5-\mathrm{HT} 2 \mathrm{CR})$ and related drug action mechanisms. However, there are still few reports about cells that contain intrinsic 5-HT2CR. This report demonstrates by using RT/PCR that 5HT2CR mRNA exists in splicing variant forms in NGI08-15 cells. The PCR results using a pair of primers that recognized sequences near the third intracellular loop site showed two neighboring bands at about $500 \mathrm{bp}$ upon electrophoresis in acrylamide gels. The sequence analysis demonstrated that one band was the rat 5-HT2CR sequence and the other one was that of the mouse. Serotonin, however, did not enhance the inositol phosphates formation in NG108-15 cells. It has been reported that post-translational modifications of RNA, splicing and editing, occur at the site of the second intracellular loop domain in 5-HT2CR mRNA. Accordingly, a pair of primers that recognized this site were designed. The molecular size of the PCR product was shorter than that expected based on the sequence of the native 5-HT2CR. The fragment lacked the 95 nucleotides of native 5-HT2CR mRNA. This seems to be the reason why serotonin did not enhance inositol phosphates formation in NG108-15 cells.
\end{abstract}

Keywords: Serotonin 2C subtype receptor, Inositolphosphate formation, Modification of RNA, RNA editing, NG108-15

The serotonin $2 \mathrm{C}$ subtype receptor $(5-\mathrm{HT} 2 \mathrm{CR})$ is the first cloned one among over 14 subtypes of serotonin receptors (1). 5-HT2CR is functionally linked to the phosphoinositide (PI) hydrolysis pathway (1) as shown in the Xenopus oocytes functional expression system, in which 5-HT2CR expression caused on outward current of $\mathrm{Cl}$ in response to PI. This oocyte system was used to perform 5-HT2CR cloning (2). 5-HT2CR is widely distributed thoughout the brain (3). The physiological functions of 5-HT2CR are involved in feeding behavior and epilepsy, as shown by results obtained with knockout mice (4). Pharmacological studies have shown that 5-HT2CR appears to be the binding site for antipsychotic drugs (5), hallucinogens (6) and antidepressants $(7,8)$. We also reported that repeated treatment with antidepressants stimulates the expression of 5-HT2CR mRNA in the rat brain $(9,10)$. To clarify the detailed mechanisms of these pharmacological actions, cultured cell systems that intrinsically express 5-HT2CR

*Corresponding author. FAX: +81-76-434-5056

E-mail: hwatanab@ms.toyama-mpu.ac.jp would be useful. There is only one report (11) mentioning the endogenous expression of 5-HT2CR in cells (Balb /c-3T3 cells), and the amount of 5-HT2CR in those cells was smaller than that of serotonin $2 \mathrm{~A}$ subtype receptor (5-HT2AR).

In this study, we found that 5-HT2CR mRNAs are expressed in NG108-15 cells, hybrid cells of mouse neuroblastoma and rat glioma, although PI turnover was not stimulated by serotonin.

\section{MATERIALS AND METHODS}

\section{Cell culture}

NGI08-15 cells were cultured in Dulbecco's modified Eagle medium (DMEM) containing HAT (100 $\mu$ M hypoxanthine, $1 \mu \mathrm{M}$ aminopterin and $16 \mu \mathrm{M}$ thymidine) and $5 \%$ fetal bovine serum at $37^{\circ} \mathrm{C}$ in a humidified atmosphere of $90 \%$ air, $10 \% \mathrm{CO}_{2}$. The culture dishes $(35 \mathrm{~mm})$ were coated with $0.1 \mathrm{mg} / \mathrm{ml}$ polyornithine (polymerization about 50) in $150 \mathrm{mM}$ borate buffer ( $\mathrm{pH} 8.4)$ to prevent detachment of the cells from the dishes. 


\section{Isolation of RNA}

Total RNA from the cells was isolated by the methods of Chomczynski and Sacchi (12). The medium was removed from the $35-\mathrm{mm}$ dish. The cells were washed once with phosphate buffered saline (PBS) and then $1 \mathrm{ml}$ of Isogen ${ }^{\circledR}$ (Nippon Gene, Toyama) was added per dish. The cell lysate was transfered to a microtube, added $0.2 \mathrm{ml} \mathrm{CHCl}_{3}$, and then centrifuged. The resultant aqueous phase was precipitated with $0.5 \mathrm{ml}$ isopropanol. The pellet was used as total RNA after washing with $70 \%$ ethanol.

\section{$R T / P C R$}

The total RNA $(2 \mu \mathrm{g})$ was incubated with oligo(dT) primer and superscript II (Gibco, Rockville, MD, USA) in a $20 \mu \mathrm{l}$ reaction mixture to make single-stranded complementary DNA (ss-cDNA). The PCR was carried out in a $10-\mu 1$ reaction mixture, containing $1 \mu \mathrm{l}$ of template sscDNA, $1 \mu \mathrm{M}$ each of forward and reverse 20 -mer primer with $50 \%$ GC content $\left(\mathrm{Tm}=55.4^{\circ} \mathrm{C}\right)$, dNTPS $(2.5 \mathrm{mM})$ and 2 units of Taq DNA polymerase (Promega, Madison, WI, USA) in the reaction buffer with $2.5 \mathrm{mM} \mathrm{MgCl}$. The primer sets for detection around the third intracellular loop site of 5-HT2CR are 5'-TTA CTT CgA ggT CAC ACC gA3' (forward) and 5'-TAA CAT TgA gCT CCC TCC CA-3' (backward) to produce a product of about 500 base pairs. Primers for around the second intracellular loop site of 5-HT2CR are 5'-Tgg CAg TAA gCA Tgg AgA Ag-3' (forward) and 5'-gAC CCg ATg AgA ACg AAg TT-3' (backward) to produce an appximately 430 base pair product of the 5-HT2CR long variant sequence. Thermocycling was performed as follows: 1) $94^{\circ} \mathrm{C}$ for $10 \mathrm{~min}$; 2) the indicated number of cycles of $94^{\circ} \mathrm{C}$ for $1 \mathrm{~min}, 56^{\circ} \mathrm{C}$ for $2 \mathrm{~min}$ and $72^{\circ} \mathrm{C}$ for $2 \mathrm{~min}$; and then 3 ) $72^{\circ} \mathrm{C}$ for $10 \mathrm{~min}$, followed by cooling to $4^{\circ} \mathrm{C}$. The products were resolved by $6 \%$ polyacrylamide gel electrophoresis and stained with SYBR gold $^{\circledR}$ (Molecular Probes, Inc., Eugene, OR, USA).

\section{Sequence of the isolated $c D N A$}

The cDNA bands amplified by PCR were cut out of the gels under UV transillumination. Each gel slice was heated to $90^{\circ} \mathrm{C}$ in $100 \mu \mathrm{l}$ of water for $12 \mathrm{~min}$. Using the supernatant as template, reamplifying PCR was carried out with the same pair of primers used in the initial reaction. The amplified DNA fragments were purified by $0.6 \%$ agarose gel electrophoresis and subcloned into the pBluescript II KS(-) vector/EcoRV site after T4 DNA polymerase treatment. The resultant vector was transfected into competent DH5a cells (Toyobo, Tsuruga) to isolate and to amplify the clone. Finally, the isolated clone was sequenced using a Hitachi-5500 sequencer (Hitachi, Tokyo).

\section{Quantification of inositol phosphates}

When the cells reached subconfluency, the culture medi- um was replaced by fresh Dulbecco's modified Eagle's medium containing HAT as well as $\left[{ }^{3} \mathrm{H}\right]$ inositol $(74 \mathrm{kBq}$ /35-mm-diameter dish) instead of unlabeled inositol, and the cultivation was continued for $17 \mathrm{~h}$. After one wash with Hepes buffered saline (HBS), cells labeled with $\left[{ }^{3} \mathrm{H}\right]$ inositol were preincubated with $950 \mu \mathrm{M}$ HBS containing $10 \mu \mathrm{M}$ $\mathrm{LiCl}$ for $5 \mathrm{~min}$ at $37^{\circ} \mathrm{C}$, and then $50 \mu \mathrm{l}$ of 20 -fold concentrated 5-HT or bradykinin was added, and the mixtures were then further incubated for $30 \mathrm{~s}$ at $37^{\circ} \mathrm{C}$. The reaction was terminated by addition of $1 \mathrm{ml}$ of $20 \%$ trichloroacetic acid, and the supernatant was washed twice with $2 \mathrm{ml}$ of water-saturated ether to remove trichloroacetic acid from the solution. The resultant solution was applied to a column $(0.6 \times 4.0 \mathrm{~cm})$ of Dowex I $\times 8$ (formate form, 200 400 mesh). After inositol and glycerophosphoinositol were eluted with $16 \mathrm{ml}$ of $5 \mathrm{mM}$ sodium tetraborate $/ 60 \mathrm{mM}$ ammonium formate, inositol phosphates were eluted sequentially by an ammonium formate step-gradient in $0.1 \mathrm{M}$ formic acid as follows: three washes with $4 \mathrm{ml}$ each of $0.2 \mathrm{M}$ for inositol monophosphate $\left(\mathrm{IP}_{1}\right)$ three washes with each $4 \mathrm{ml}$ of $0.4 \mathrm{M}$ for inositol bisphosphate $\left(\mathrm{IP}_{2}\right)$ and $4 \mathrm{ml}$ of $1.0 \mathrm{M}$ for inositol trisphosphate $\left(\mathrm{IP}_{3}\right)$. The radioactivity of each fraction (totally 7 fractions for each sample) was measured after addition of the scintillation cocktail, Clearsol $^{\circledR}$ (Nacalai Tesque, Kyoto). The blank values which were obtained from the same volume of elution solution were subtracted from each value, and three values in the case of $\mathrm{IP}_{1}$ and $\mathrm{IP}_{2}$ were added up to result. Statistical significance was assessed by Student's $t$-test.

\section{RESULTS}

The total RNA isolated from confluent NG108-15 cells was used to perform RT/PCR. The PCR products amplified using the primer set for the third intracellular loop site of 5-HT2CR showed a double band at about 500 bp in polyacrylamide gel electrophoresis (Fig. 1A). The PCR products were not amplified from contaminating genomic DNA, since they were not detected in samples without RT reaction (Fig. 1A, RNA 1) even from 20-fold concentrated samples without RT (Fig. 1A, RNA 20). Each band was subjected to reamplification by PCR and the resultant products also showed a small difference in size (Fig. 1B). These two PCR products were subcloned and subjected to nucleotide sequencing. The sequencing results showed that the longer product had the same sequence as the rat 5HT2CR sequence (accession No. M21410), while the sequence of the shorter product was identical with that of mouse 5-HT2CR (M63685) (Fig. 2A). As shown in Fig. 2A, the length of the reported mouse sequence is three bases shorter than the rat sequence in the third intracelluler loop site. The sequencing gel electrophoresis image also showed a three-base difference at this site (Fig. 2B). These results 


\section{A) RT/PCR}

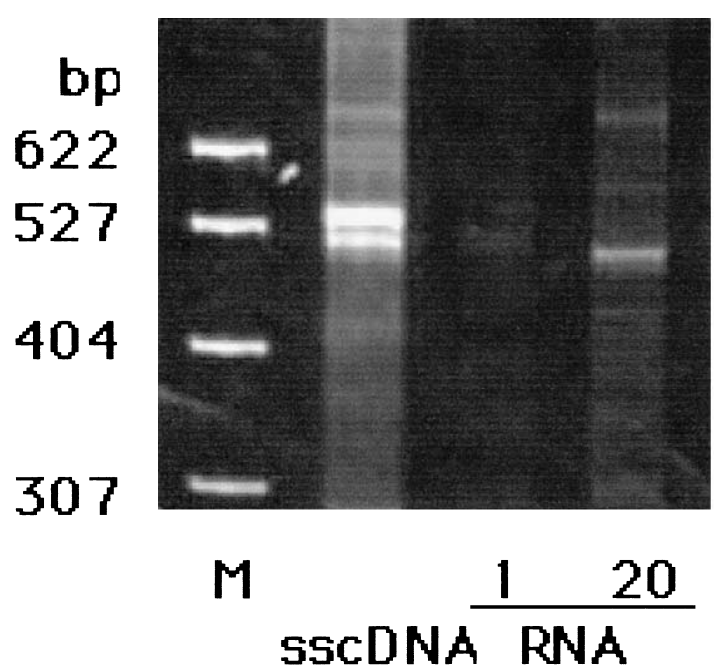

\section{B) reamplification}
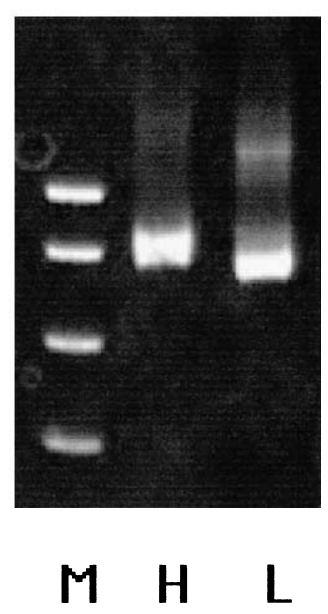

Fig. 1. The PCR detection of 5-HT2CR mRNA in NG108-15 cells. RNAs were isolated from NG108-15 cells by the acidic phenol method. RT/PCR was performed using a primer set that detected a region around the third intracellular loop of 5-HT2CR (sscDNA). A) Two bands were seen near the 527-bp molecular marker (M). To certify that there was no contamination of genomic DNA in RNA samples, PCR was performed without RT. The same amount (1) and a 20-fold greater amount (20) of RNA was subjected to the PCR. B) The two products obtained by PCR shown in A were recovered from the gel individually and reamplification by PCR was carried out.

indicate that the both mouse and rat 5-HT2CR are expressed in NG108-15 cells.

It is well known that 5-HT2CR mediates PI turnover. Therefore the synthesis of inositol phosphates induced by 5-HT stimulation in NG108-15 cells was examined. Contrary to our expectation, inositol phosphate formation was not enhanced by 5-HT treatment (Fig. 3).

The short variant and the substitution of some bases in the structure around the second intracellular loop site of 5HT2CR have been reported (13). To examine this region, we designed an appropriate primer set to detect the second intracelluler loop site and performed RT-PCR. The RT /PCR product from the rat brain total RNA consisted of one major band on polyacrylamide gel electrophoresis; this band was about 430-bp long, which was the expected size according to the reported 5-HT2CR sequence (Fig. 4, lane Rat). On the other hand, the RT/PCR product from the RNA of NG108-15 cells showed a shorter main band at around $340 \mathrm{bp}$ (Fig. 4, lane NG). This shorter band was isolated, reamplified and sequenced as in the case of the third intracellular loop domain described above. The sequence analysis revealed a 95-nucleotides (nt) deletion in this PCR product compared to that from rat brain (Fig. 5).

\section{DICUSSION}

NG108-15 cells intrinsically express some receptor subtypes that stimulate PI turnover, including receptors of bradykinin B2 (14), histamine H1 (15), purinergic P2 (16), opiate (17), endothelin (18) and angiotensin (19). Since the intracellular signaling systems of PI turnover in NG108-15 are highly developed, the cell is often used to study the cellular physiological functions of inositolphosphate and related systems $(20,21)$, and it is used as a host cell for transfection studies of PI turnover-coupled receptors (22, 23). The 5-HT2CR are of the PI turnover-coupled type, and in this report the mRNA for these receptors was detected by RT/PCR in NG108-15 cells. Contaminating genomic DNA did not affect the detection, because PCR performed without RT did not amplify the 5-HT2CR band (Fig. 1). Although 5-HT2CR mRNA exists in NG108-15 cells when a primer set detecting around the third intracellular domains was used, PI turnover was not enhanced by the addition of 1 to $1,000 \mu \mathrm{M} 5$-HT. There are some possible reasons for this. One possibility is that other categories of 5-HT receptors possessing in NG108-15 cells, such as 5-HT3 (24) and 5 -HTGC $(25,26)$, inhibit PI turnover by raising intracellular $\mathrm{Ca}^{2+}$ or cGMP concentrations. We also detected 5HT1AR mRNA, but not 5-HT2AR mRNA, by the same methods as used in this report (data not shown). The possibility that other types of 5-HT receptors may contribute to inhibition of PI turnover may be denied from our preliminary results that $1-(m$-chlorophenyl)piperazine ( $m$-CPP), a selective agonist of 5-HT2CR, could not enhance the intra- 


\begin{abstract}
A)
1) tttct gaactgctgc tgcaagaaga atggtggtga

2) tttct gaactgctgc tgcaagaaga atggtggtga

3) tttct aaagtgctgc tgcaagaag ggtgatga

$4)$ tttct aaagtgctgc tgcaagaag ggtgatga

ggaagagaac gctccgaacc ctaatccaga tcagaaacca cgtcgaaaga ggaagagaac gctccgaacc ctaatccaga tcagaaacca cgtcgaaaga ggaagagaac gctcccaacc ccaatccaga tcagaagcca cgtcgaaaga ggaagagaac gctcccaacc ccaatccaga tcagaagcca cgtcgaaaga

agaaagaaa gcgtcccaga ggcaacatgc aagctatcaa caacgaaaag agaaagaaa gcgtcccaga ggcaccatgc aagctatcaa caacgaaaag agaaagaaa gcggcctaga ggcaccatgc aagctatcaa caatgagaag agaaagaaa gcggcctaga ggcaccatgc aagctatcaa caatgagaag

aaagcttcca aagtccttgg cattgtattc tttgtgtttc tgatcatgtg aaagcttcca aagtccttgg cattgtattc tttgtgtttc tgatcatgtg aaagcttcca aagtccttgg cattgtattc tttgtgtttc tgatcatgtg aaagcttcca aagtccttgg cattgtattc tttgtgtttc tgatcatgtg

gtgcccgttt ttcatcacca atatcctgtc ggttctttgt gggaaggcct gtgcccgttt ttcatcacca atatcctgtc ggttctttgt gggaaggcct gtgcccgttt ttcatcacca atatcctgtc ggtgctttgt gggaaggcct gtgcccgttt ttcatcacca atatcctgtc ggtgctttgt gggaaggcct

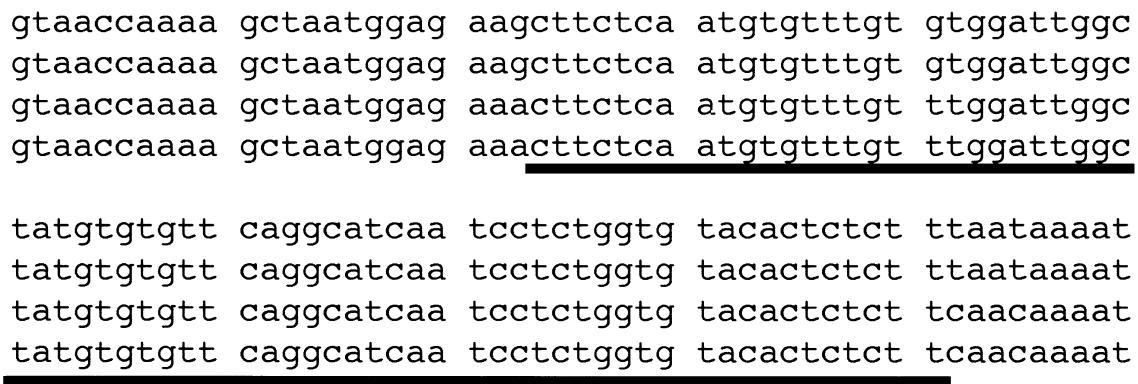

B)

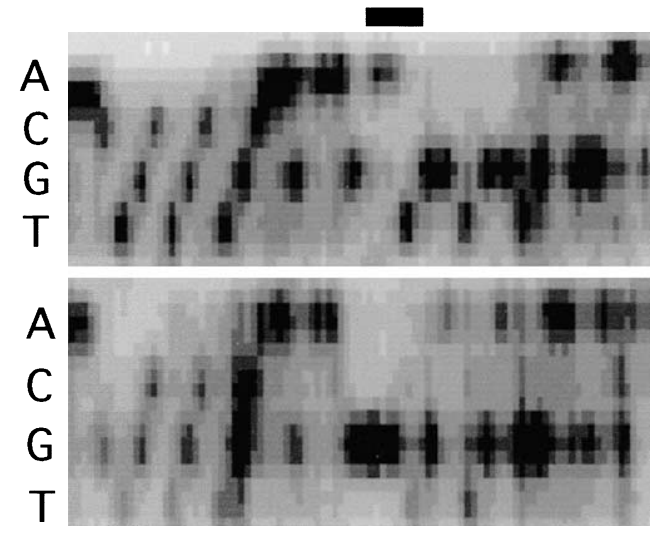

Fig. 2. Sequence analysis of the PCR products. A) The sequences are 1) rat 5-HT2CR cDNA reported by Julius et al. (M21410) (ref. 33), 2) high molecular weight band amplified from NG108-15 cell RNA (shown in Fig. 1B, lane H), 3) low molecular weight band amplified from NG108-15 cell RNA (shown in Fig. 1B, lane L) and 4) mouse 5-HT2CR cDNA sequence reported by Yu et al. (M63685) (unpublished). The transmembrane domains are underlined. These sequences correspond to the area between the third and fourth intracellular domains of 5-HT2CR. Notice that the mouse sequence is three bases shorter than the rat sequence. B) Sequencing gel images showing the three-base deletion in mouse 5-HT2CR cDNA. The upper image is from the high molecular weight band from NG10815 cells and the lower is from the low molecular weight band. The bases "att" (indicated by a bar) can not be seen in the lower image. cellular $\mathrm{Ca}^{2+}$ concentration in fura-2AM preloaded NG10815 cells (data not shown). The inhibitory effect of 5-HT on PI turnover at $1,000 \mu \mathrm{M}$ seems to be a non-specific one due to this very high concentration of 5-HT. The possibility that some kind of factor inhibited the translation of 5-HT2CR mRNA to protein is also not ruled out. However, Canton et al. (13) detected a short variant of 5-HT2CR mRNA produced by alternative splicing. This short variant con- 

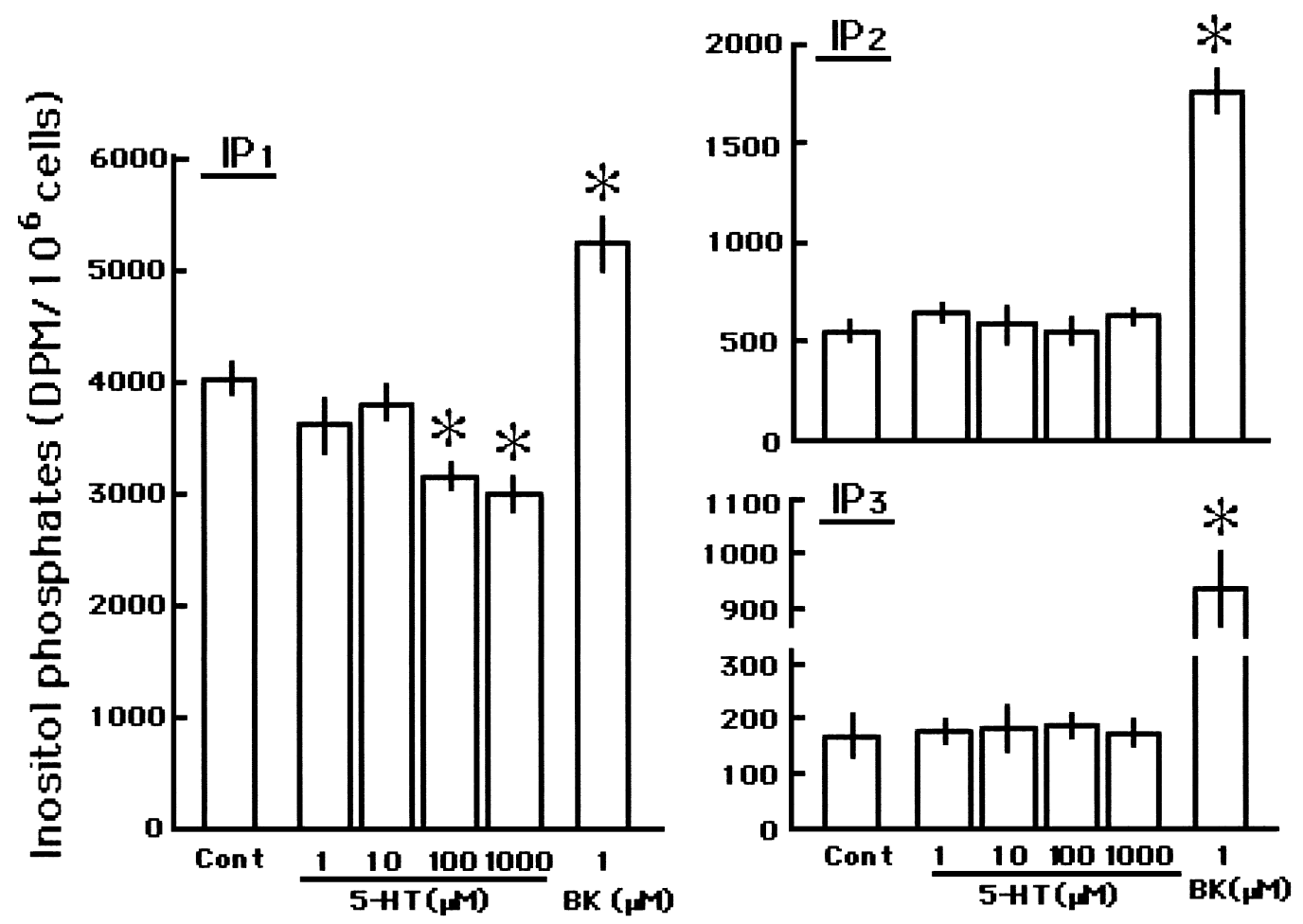

Fig. 3. Effects of 5-HT and bradykinin on inositol phosphate formation in NG108-15 cells. Cellular phosphoinositides were prelabeled by incubation of cells for $17 \mathrm{~h}$ in culture medium containing $\left[{ }^{3} \mathrm{H}\right]$ inositol without unlabeled inositol. The inositol phosphates $\left(\mathrm{IP}_{1}, \mathrm{IP}_{2}\right.$ and $\left.\mathrm{IP}_{3}\right)$ were quantified at $30 \mathrm{~s}$ after addition of 5-HT or bradykinin in buffer containing $10 \mathrm{mM} \mathrm{LiCl}$ to inhibit $\mathrm{IP}_{1}$ phosphatase. Data are the mean \pm S.E.M. values of 4 experiments. ${ }^{*} P<0.01$ vs control.

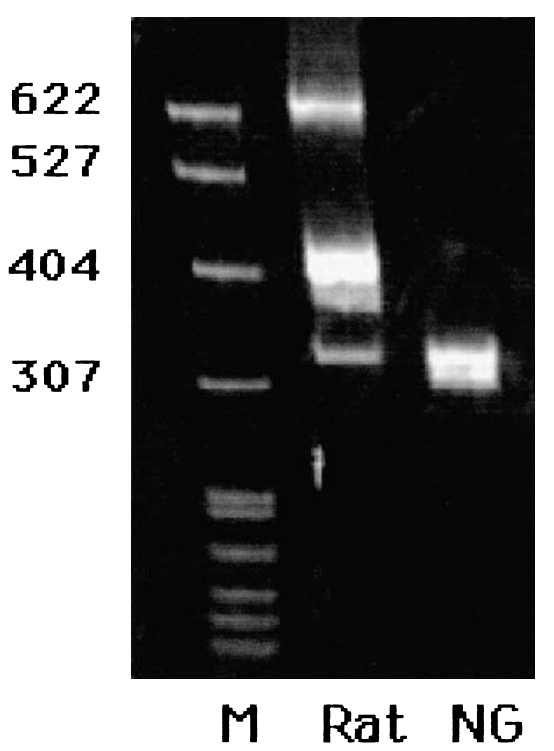

Fig. 4. RT-PCR detection of 5-HT2CR mRNA in rat brain and NG108-15 cells. RNA was isolated from rat brain (Rat) and NG10815 (NG) cells by the acidic phenol method. RT/PCR was performed using a primer set that detected the region around the second intracellular loop of 5-HT2CR. M, molecular marker: Msp I-digested pBR322 plasmid with bands of $622,527,404,307 \mathrm{bp}$ and other sizes. tains a deletion of a $95 \mathrm{nt}$ sequence in the region between the second intracellular and fourth transmembrane domains of 5-HT2CR. Therefore, we designed primer sets that recognized this area. Surprisingly, only the short variant of 5-HT2CR mRNA could be detected in NG108-15 cells. The deletion leads to a frameshift. Since 5-HT2CR protein can not be produced from the deleted mRNA (13), this deletion may be the reason why PI turnover was not stimulated by 5-HT in NG108-15 cells. Studies using antibodies would be able to examine this possibility.

The deleted $95 \mathrm{nt}$ includes the RNA editing site. In RNA editing, genomically encoded adenosine residues are converted to inosines by a specific adenosine deaminase (27). The edited RNA thus generates proteins that contain amino acids not encoded by the original transcript. Among receptors, the AMPA type of glutamate receptor $(28,29)$ and 5 -HT2CR (30) are affected by this event. In the case of 5 -HT2CR, five residues in the second transmembrane coding region can be edited, resulting in a change of three amino acids (31). It has been suggested that this editing in 5-HT2CR affects the G-protein coupling with the receptor (32). Since both events are mediated by the second transmembrane domain, it will be of interest to determine whether RNA editing is involved in the $95 \mathrm{nt}$ deletion of 5-HT2CR. 


\title{
A)
}

\author{
781 tggcagtaag catggagaag aaactgcaca atgctaccaa ttatttctta atgtccctag \\ tggcagtaag catggagaag aaactgcaca atgctaccaa ttatttctta atgtccctag \\ 841 ccattgctga tatgctggtg ggactacttg tcatgcccct gtctctgctt gcaattcttt \\ ccattgctga tatgctggtg ggactacttg tcatgcccct gtctctgctt gcaattcttt \\ 901 atgattatgt ctggccttta cctagatatt tgtgccccgt ctggatttca ctagatgtgc \\ atgattatgt ctggcctta cctagatatt tgtgcccogt ctggatttca ctagatgtgc \\ 961 tattttcaac tgcgtccatc atgcacctct gcgccatatc gctggaccgg tatgtagcag \\ tattttcaac tgcgtccatc atgcacctct gcgccatatc gctggaccgg
}

1021 tgcgtagtcc tgttgagcat agccggttca attcgcggac taaggccatc atgaagattg

\begin{abstract}
1081 ccatcgtttg ggcaatatca ataggagttt cagttcctat ccctgtgatt ggactgaggg agttt cagttcctat ccctgtgatt ggactgaggg

1141 acgaaagcaa agtgttcgtg aataatacta cctgcgtgct caatgacccg aacttcgttc acgaaagcaa agtgttcgtg aataatacta cctgcgtgct caatgacccg aacttcgttc

1201 tcatcgggtc cttcgtggca ttcttcatcc cgttgacaat tatggtgatc acctacttct tcatcgggtc
\end{abstract}

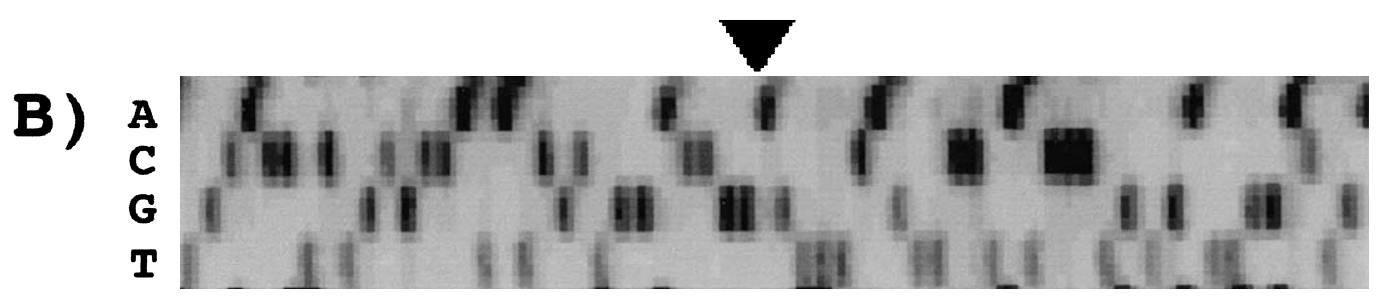

Fig. 5. The sequence of PCR products highly expressed in NG108-15 cells detected using a primer set for the region around the second intracellular domain of 5-HT2CR. The upper sequence is that of mouse 5-HT2CR cDNA reported by Yu et al. (M63685, unpublished). The lower one is that of the isolated PCR product of NG108-15 cells. Notice that $95 \mathrm{nt}$ were deleted from the sequence of NG108-15 compared with the mouse sequence. The deleted sequence contained the second intracellular domain of 5HT2CR. B) The sequencing gel image in the region of the deletion in NG108-15 cells. The deleted sequence region is indicated by a triangle.

Julius et al., who cloned 5-HT2CR (the previous name was 5-HT1C) (2), showed that the transfection of 5-HT2CR cDNA into NIH3T3 fibroblast cells resulted in the generation of transformed foci (33). They probably transfected the edited sequence, because the sequence that they cloned was reported to contain guanosine instead of adenosine residues in 4 of the 5 editable positions. We propose the following hypothesis. The edited mRNA and the protein translated from this mRNA may stimulate cellular growth rather than transmembrane signaling. If the editing is involved in the short variant formation, the protein product of the short variant, which is clearly a different protein from 5-HT2CR, may have a role in regulating growth. NG108-15 and other cloned cell lines have high growth potential, and NG108-15 cells were found here to contain the short variant of 5HT2CR mRNA. This might be the reason why there are few reports about endogenous expression of 5-HT2CR in cloned cell lines, although the distribution of 5-HT2CR within brain is considerable and widespread (3). Further studies are necessary to clarify the cellular function of the short variant of 5-HT2CR including the relationship with cell growth and RNA editing. NG108-15 cells may be a useful tool to know that.

\section{Acknowledgments}

We gratefully thank Professor Dr. Haruhiro Higashida, Kanazawa University Graduate School of Medicine, Japan, for his helpful advice. This work was supported in part by a Grant-in-Aid for Scientific Research (B) to Dr. M. Tohda (\#124770194) form the Ministry of Education, Culture, Sports, Science and Technology, Japan and by a grant from the First-Bank of Toyama Foundation to Dr. Tohda.

\section{REFERENCES}

1 Boess F and Martin IL: Molecular biology of 5-HT receptors. Neuropharmacology 33, 275 - 317 (1994)

2 Julius D, MacDermott AB, Axel R and Jessell TM: Molecular characterization of a functional cDNA encoding the serotonin $1 \mathrm{c}$ 
receptor. Science 241, 558 - 564 (1988)

3 Molineaux SM, Jessell TM, Axel R and Julius D: 5-HT1c receptor is a prominent serotonin receptor subtype in the central nervous system. Proc Natl Acad Sci USA 86, 6793-6797 (1989)

4 Tecott LH, Sun LM, Akana SF, Strack AM, Lowenstein DH, Dallman MF and Julius D: Eating disorder and epilepsy in mice lacking 5-HT2c serotonin receptors. Nature 374, 542-546 (1995)

5 Rauser L, Savage JE, Meltzer HY and Roth BL: Inverse agonist actions of typical and atypical antipsychotic drugs at the human 5-hydroxytryptamine ${ }_{2 \mathrm{C}}$ receptor. J Pharmacol Exp Ther 299, $83-89$ (2001)

6 Newton RA, Phipps SL, Flanigan TP, Newberry NR, Carey JE, Kumar C, McDonald B, Chen C and Elliott JM: Characterisation of human 5-hydroxytryptamine2A and 5-hydroxytryptamine2C receptors expressed in the human neuroblastoma cell line SH-SY5Y: comparative stimulation by hallucinogenic drugs. J Neurochem 67, 2521 - 2531 (1996)

7 Palvimaki EP, Roth BL, Majasuo H, Laakso A, Kuoppamaki M, Syvalahti $\mathrm{E}$ and Hietala J: Interactions of selective serotonin reuptake inhibitors with the serotonin 5-HT2c receptor. Psychopharmacology (Berl) 126, 234 - 240 (1996)

8 Tohda M, Takasu T and Nomura Y: Effects of antidepressants on serotonin-evoked current in Xenopus oocytes injected with rat brain mRNA. Eur J Pharmacol 166, 57 - 63 (1989)

9 Tohda $\mathrm{M}$ and Watanabe $\mathrm{H}$ : Imipramine-induced increase in 5HT2C receptor mRNA level in the rat brain. Neurosci Res 24, $189-193$ (1996)

10 Tohda M, Abdel-Fattah AM, Nakamura S and Watanabe $\mathrm{H}$ : Effects of Hochu-ekki-to (Bu-Zhong-Yi-Qi-Tang), a Kampo medicine, on serotonin $2 \mathrm{C}$ subtype receptor-evoked current response and the receptor mRNA expression. J Trad Med 17, $34-40(2000)$

11 Saucier C, Morris SJ and Albert PR: Endogenous serotonin-2A and $-2 \mathrm{C}$ receptors in $\mathrm{Balb} / \mathrm{c}-3 \mathrm{~T} 3$ cells revealed in serotonin-free medium: desensitization and down-regulation by serotonin. Biochem Pharmacol 56, 1347 - 1357 (1998)

12 Chomczynski P and Sacchi N: Single-step method of RNA isolation by acid guanidinium thiocyanate-phenol-chloroform extraction. Anal Biochem 162, 156 - 159 (1987)

13 Canton H, Emeson RB, Barker EL, Backstrom JR, Lu JT, Chang MS and Sanders-Bush E: Identification, molecular cloning, and distribution of a short variant of the 5-hydroxytryptamine2C receptor produced by alternative splicing. Mol Pharmacol 50, $799-807$ (1996)

14 Yano K, Higashida H, Inoue R and Nozawa Y: Bradykinininduced rapid breakdown of phosphatidylinositol 4,5-bisphosphate in neuroblastoma $\times$ glioma hybrid NG108-15 cells. J Biol Chem 259, 10201 - 10207 (1984)

15 Tohda M and Nomura Y: Effects of histamine on polyphosphoinositide metabolism in NG108-15 cells. Neurochem Int 14, $73-78$ (1989)

16 Lin TA, Lustig KD, Sportiello MG, Weisman GA and Sun GY: Signal transduction pathways coupled to a P2U receptor in neuroblastoma $\times$ glioma (NG108-15) cells. J Neurochem 60, 1115 - 1125 (1993)

17 Chueh SH, Song SL and Liu TY: Heterologous desensitization of opioid-stimulated $\mathrm{Ca}^{2+}$ increase by bradykinin or ATP in
NG108-15 cells. J Biol Chem 270, 16630 - 16637 (1995)

18 Yue TL, Nambi P, Wu HL and Feuerstein G: Endothelin receptor binding and cellular signal transduction in neurohybrid NG108-15 cells. Neuroscience 44, 215 - 222 (1991)

19 Speth RC, Mei L and Yamamura HI: Angiotensin II receptor binding and actions in NG108-15 cells. Pept Res 2, 232-239 (1989)

20 Higashida H, Yokoyama S, Hoshi N, Myojo Y, Kawamura T, Ito Y, Hashii M, Sagara J and Furuya K: Phosphoinositides and synaptic function in NG108-15 neuroblastoma $\times$ glioma hybrid cells. Comp Biochem Physiol C 98, 129 - 137 (1991)

21 Higashida H, Hashii M, Yokoyama S, Hoshi N, Chen XL, Egorova A, Noda M and Zhang JS: Cyclic ADP-ribose as a second messenger revisited from a new aspect of signal transduction from receptors to ADP-ribosyl cyclase. Pharmacol Ther 90, $283-296$ (2001)

22 Fukuda K, Higashida H, Kubo T, Maeda A, Akiba I, Bujo H, Mishina $\mathrm{M}$ and Numa S: Selective coupling with $\mathrm{K}^{+}$currents of muscarinic acetylcholine receptor subtypes in NG108-15 cells. Nature 335, 355 - 358 (1988)

23 Tohda M, Tohda C, Sakuma S, Higashida H and Nomura Y: Distinct induction of c-fos mRNA in NG108-15 cells transfected with muscarinic $\mathrm{m} 1$ and $\mathrm{m} 3$ receptors. Eur J Pharmacol 268, 169 - 176 (1994)

24 Ronde P and Nichols RA: Postsynaptic target regulates functional responses induced by 5 -HT3 serotonin receptors on axonal varicosities of NG108-15 hybrid neuroblastoma cells. Neuroscience 102, 979 - 987 (2001)

25 Tohda M, Imaizumi R, Sekiya A, Itoh N and Nomura Y: Studies on the activation mechanisms of guanylyl cyclase by serotonin, probably through a novel subtype of serotonin receptor (5HTGC). Biol Pharm Bull 18, 1072 - 1075 (1995)

26 Tohda M, Sakuma I and Nomura Y: The slow cyclic GMP increase caused by serotonin in NG108-15 cells is not inhibited by antagonists of known serotonin receptors: possible existence of a new receptor subtype coupled with membrane-bound guanylate cyclase. J Neurochem 57, 714 - 717 (1991)

27 Simpson L and Emeson RB: RNA editing. Annu Rev Neurosci 19, 27 - 52 (1996)

28 Sommer B, Kohler M, Sprengel R and Seeburg PH: RNA editing in brain controls a determinant of ion flow in glutamate-gated channels. Cell 67, $11-19$ (1991)

29 Seeburg PH: The role of RNA editing in controlling glutamate receptor channel properties. J Neurochem 66, 1 - 5 (1996)

30 Fitzgerald LW, Iyer G, Conklin DS, Krause CM, Marshall A, Patterson JP, Tran DP, Jonak GJ and Hartig PR: Messenger RNA editing of the human serotonin 5-HT2C receptor. Neuropsychopharmacology 21, Suppl, 82S - 90S (1999)

31 Niswender CM, Copeland SC, Herrick-Davis K, Emeson RB and Sanders-Bush E: RNA editing of the human serotonin 5hydroxytryptamine $2 \mathrm{C}$ receptor silences constitutive activity. J Biol Chem 274, 9472 - 9478 (1999)

32 Price RD, Weiner DM, Chang MS and Sanders-Bush E: RNA editing of the human serotonin 5-HT2C receptor alters receptormediated activation of G13 protein. J Biol Chem 276, 44663 44668 (2001)

33 Julius D, Livelli TJ, Jessell TM and Axel R: Ectopic expression of the serotonin $1 \mathrm{c}$ receptor and the triggering of malignant transformation. Science 244, 1057 - 1062 (1989) 